\title{
Genomic analysis of the response of mouse models to high-fat feeding shows a major role of nuclear receptors in the simultaneous regulation of lipid and inflammatory genes
}

Citation for published version (APA):

Kreeft, A. J., Moen, C. J., Porter, G., Kasanmoentalib, S., Sverdlov, R., van Gorp, P. J. J., Havekes, L. M., Frants, R. R., \& Hofker, M. H. (2005). Genomic analysis of the response of mouse models to high-fat feeding shows a major role of nuclear receptors in the simultaneous regulation of lipid and inflammatory genes. Atherosclerosis, 182(2), 249-257. https://doi.org/10.1016/j.atherosclerosis.2005.01.049

Document status and date:

Published: 01/01/2005

DOI:

10.1016/j.atherosclerosis.2005.01.049

Document Version:

Publisher's PDF, also known as Version of record

\section{Document license:}

Taverne

\section{Please check the document version of this publication:}

- A submitted manuscript is the version of the article upon submission and before peer-review. There can be important differences between the submitted version and the official published version of record. People interested in the research are advised to contact the author for the final version of the publication, or visit the DOI to the publisher's website.

- The final author version and the galley proof are versions of the publication after peer review.

- The final published version features the final layout of the paper including the volume, issue and page numbers.

Link to publication

\footnotetext{
General rights rights.

- You may freely distribute the URL identifying the publication in the public portal. please follow below link for the End User Agreement:

www.umlib.nl/taverne-license

Take down policy

If you believe that this document breaches copyright please contact us at:

repository@maastrichtuniversity.nl

providing details and we will investigate your claim.
}

Copyright and moral rights for the publications made accessible in the public portal are retained by the authors and/or other copyright owners and it is a condition of accessing publications that users recognise and abide by the legal requirements associated with these

- Users may download and print one copy of any publication from the public portal for the purpose of private study or research.

- You may not further distribute the material or use it for any profit-making activity or commercial gain

If the publication is distributed under the terms of Article 25fa of the Dutch Copyright Act, indicated by the "Taverne" license above, 


\title{
Genomic analysis of the response of mouse models to high-fat feeding shows a major role of nuclear receptors in the simultaneous regulation of lipid and inflammatory genes
}

\author{
Arja J. Kreeft ${ }^{\mathrm{a}, 1}$, Corina J.A. Moen ${ }^{\mathrm{a}, 1}$, Gordon Porter ${ }^{\mathrm{b}}$, Soemini Kasanmoentalib ${ }^{\mathrm{c}}$, \\ Ronit Sverdlov ${ }^{\mathrm{d}}$, Patrick J. van Gorp ${ }^{\mathrm{d}}$, Louis M. Havekes ${ }^{\mathrm{e}}$, Rune R. Frants ${ }^{\mathrm{a}}$, \\ Marten H. Hofker ${ }^{d}$,*

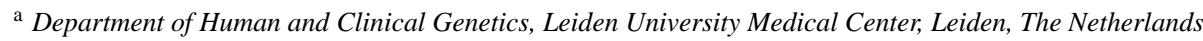 \\ ${ }^{\mathrm{b}}$ Incyte Genomics, Palo Alto, CA, USA \\ ${ }^{\mathrm{c}}$ Department of Clinical Epidemiology and Biostatistics, Free University Medical Center, Amsterdam, The Netherlands \\ ${ }^{d}$ Cardiovascular Research Institute Maastricht, Department of Molecular Genetics, Universiteit Maastricht UNS50/11, \\ P.O. Box 616, 6200MD Maastricht, The Netherlands \\ e TNO-PG and Department of Cardiology and Internal Medicine, LUMC, Leiden, The Netherlands
}

Received 21 May 2004; received in revised form 14 January 2005; accepted 27 January 2005

Available online 16 March 2005

\begin{abstract}
The mechanisms of diet induced hyperlipidemia and atherosclerosis have been widely studied by delineating the role of candidate genes in transgenic and gene targeted mouse models. However, diet induced hyperlipidemia represents a complex process determined by many lipid genes that is only partly understood. This study is aimed at delineating the events induced by dietary intervention in different mouse models at the level of gene expression using microarray analysis. The focus is on the liver as the organ primarily responding to diet, and crucial in determining plasma lipid levels. Firstly, the effect of the genotype was studied. Expression profiles of liver genes were compared between APOE3Leiden (E3L), APOE knockout (E-/-) and C57BL/6JIco (B6) mice using the Incyte GEM 2.03 array carrying 9552 genes. Several hundred differentially expressed genes were identified indicating that the genotype alone effects gene expression. Secondly, the response of E3L mice to high-fat feeding was investigated using a mild and severe high-fat diet (diet W and N, respectively). Diet W caused differential regulation of 200 genes, while diet $\mathrm{N}$ affected the expression of 788 genes in $\mathrm{B} 6$ and 1010 genes in E3L mice. Annotation of these genes using the Gene Ontology (GO) database showed that two major processes were strongly affected by genotype and diet, namely lipid metabolism and inflammation, the latter as determined by "immune/defense response and detoxification" processes. Many nuclear receptor target genes were differentially regulated, with the largest effects modulated by the severe high-fat diet $\mathrm{N}$, leading to the suppression of genes involved in bile acid, sterol, steroid, fatty acid, and detoxification metabolism. Strikingly, a substantial part of these nuclear receptor target genes were commonly regulated during the different experimental conditions. The common regulation of many nuclear receptor target genes underlying lipid and detoxification processes as found in this study, suggest a defense mechanism involving many nuclear receptors to protect against the accumulation of toxic endogenous lipids and bile acids. These results further strengthen the close link between hyperlipidemia and inflammatory processes.
\end{abstract}

(C) 2005 Elsevier Ireland Ltd. All rights reserved.

Keywords: Hyperlipidemia; Transgenic mice; Gene expression profiles; Nuclear receptor target genes

\footnotetext{
* Corresponding author. Tel.: +31 43388 1138; fax: +31 433884574

E-mail address: m.hofker@gen.unimaas.nl (M.H. Hofker).

${ }^{1}$ Both authors contributed equally to this paper.
}

\section{Introduction}

Transgenic mice with an altered lipoprotein metabolism have been instrumental for the molecular and biochemical 
analysis of hyperlipidemia and atherosclerosis. In particular, knock out and transgenic mice based on the APOE gene, such as the APOE knock out (E-/-) mouse and the APOE3Leiden (E3L) mouse have been widely used. These mice are characterized by a severe reduction of the clearance of VLDL remnants, which leads to increased plasma lipid levels and results in significant diet induced changes in the lipoprotein metabolism [1,2]. The E3L mouse proved to be particularly useful to study the effect of diet on lipoprotein levels, because their lipid profile resembles those of humans. Hence, E3L mice fed a "western type diet" will develop high levels of triglycerides and cholesterol. For atherosclerosis induction in mice, diets are used that typically contain cholesterol and bile acids [3,4]. Despite our advanced knowledge of the genes involved in hyperlipidemia and atherosclerosis, much is based on the description of a selection of $\sim 2000$ genes that are well known. At present, however, all of the 27,000-30,000 mouse genes have been sequenced and can be accessed via databases. To begin to explore which of these genes could be linked to hyperlipidemia and/or atherosclerosis, we have studied the expression patterns of 9552 genes in liver using microarray analysis. The liver was chosen because it is the major organ determining plasma lipid levels, and can also respond to other physiological challenges by orchestrating the primary defense against toxic lipids.

To obtain a better understanding of the mechanisms underlying hyperlipidemia and atherosclerosis, two related approaches were used. Microarray analysis was used to study the effect of genetically altering the lipoprotein metabolism in mice, to see which functionally related genes would become deregulated. To this end, the gene expression in the livers of the E3L mice and the E-/- mice have been compared with the wild type C57BL/6 (B6) strain. To study if these effects would be exacerbated by different dietary interventions, microarray analysis was used to evaluate the effect of mild and severe high-fat feeding in the liver. Therefore, we fed the susceptible E3L mice a mild and severe highfat diet and compared these mice with chow fed controls. We assume that genes that are commonly regulated during the different conditions are of particular interest for further study, because these genes may play instrumental roles under hyperlipidemic conditions.

These approaches were expected to identify a large number of differentially regulated genes. To be able to validate our hypothesis that these genes were related to the lipoprotein metabolism, we made use of recent developments in bioinformatics to annotate the output files of these microarray experiments. One of the most useful resources is the "Gene Ontology (GO) database", that is a database containing consistent descriptions of genes in terms of their associated biological processes, molecular functions and cellular compartments in a species-independent manner [5]. Interestingly, this database allows annotation of genes at different levels, depending on how much is known about a gene product. When applied to the complete content of the chip and to the output file of the chip, it should be possible to define functional classes that become particularly regulated, while other classes would not show such an over representation. Another useful resource that was used is the Kyoto Encyclopedia of Genes and Genomes (KEGG) database containing specific information on metabolic pathways [6].

The consequences of high-fat feeding on the gene expression profile in liver is likely to be complex, because numerous components have an effect on gene regulation, such as sugars and lipids, which are either present in the diet or derived during further metabolism. This study mainly focuses on the genes that are involved in the metabolism of lipids. Interestingly, the knowledge in this field has increased substantially due to the discovery of a large series of transcription factors that are directly regulated by lipids. These transcription factors include the sterol regulatory element binding proteins (SREBPs), acting as cholesterol sensors, and nuclear receptors, including the farnesoid X receptor (FXR), pregnane $\mathrm{X}$ receptor (PXR), constitutive androstane receptor (CAR), liver $\mathrm{X}$ receptor (LXR) and peroxisome proliferator activated receptors (PPARs), which are being activated by bile acids, oxysterols and fatty acids, respectively [7]. These known regulatory pathways allow further annotation of the genes detected in this study, and build towards a network of genes of which the expression is influenced by diet.

\section{Methods}

\subsection{Animals}

Transgenic E3L mice (line \#2), expressing the human APOE3Leiden and human APOC1 genes and E-/- mice have been described previously $[1,8]$. Twenty-seven female E3L mice of the N21th generation (>99\% on a B6 genetic background), 10 female $\mathrm{E}-/$ - (on a B6 genetic background) and 20 female B6 mice were used in experiments. Mice received standard diet (chow, Hopefarms, The Netherlands, $3883 \mathrm{kcal} / \mathrm{kg}$ ), a mild HFC diet (diet W, Hopefarms, The Netherlands, $4350 \mathrm{kcal} / \mathrm{kg}$ ) containing per 100 grams (g), cocoa butter $15 \mathrm{~g}$, corn oil $1 \mathrm{~g}$, sucrose $40.5 \mathrm{~g}$, corn starch $10 \mathrm{~g}$, and cholesterol $0.25 \mathrm{~g}$ and an 'atherogenic' high fat high cholesterol (HFC) diet (diet N, Hopefarms, $4356 \mathrm{kcal} / \mathrm{kg}$ ), known to elicit fatty streak lesions in aortas of susceptible mice, containing per 100 grams, cocoa butter $15 \mathrm{~g}$, corn oil $1 \mathrm{~g}$, sucrose $40.5 \mathrm{~g}$, corn starch $10 \mathrm{~g}$, cholesterol $1 \mathrm{~g}$ and cholate $0.5 \mathrm{~g}$ [3]. Ten B6, $10 \mathrm{E}-/-$ and $10 \mathrm{E} 3 \mathrm{~L}$ mice on chow diet were sacrificed at 10 weeks of age and used for experiments. Seven E3L mice received diet $\mathrm{W}$ for 4 weeks and 10 B6 and $10 \mathrm{E} 3 \mathrm{~L}$ mice received diet $\mathrm{N}$ for a period of 8 weeks. Mice were 10 weeks of age at the start of dietary treatment. Mice were housed under standard conditions in conventional cages with free access to food and water.

\subsection{Measurement of serum lipids}

After the dietary treatment period from each individual mouse, $200 \mu \mathrm{l}$ blood was collected in a microvette tube 
(Sarstedt), after a 4-h fasting period. Total serum cholesterol (TC) (kit no. 236691, Boehringer Mannheim) and triglyceride without free glycerol (TTG) (kit no. 337-B, Sigma) were measured enzymatically. The day after bleeding, mice were sacrificed by cervical dislocation and the liver was removed and immediately deep frozen in liquid nitrogen and stored at $-80^{\circ} \mathrm{C}$. A small piece of the liver was fixed in $4 \%$ neutral-buffered formalin, processed, and embedded in paraffin. Three-micrometer sections were stained with hematoxylin-phloxine-saffron (HPS) and examined microscopically.

\subsection{Microarray probing and data analysis}

High quality total RNA from the caudate liver lobe was isolated using RNA STAT-60 (Tel-Test Inc., Friendswood, TX) according to the manufacturer's protocol. Subsequently, total RNA was pooled from individual mice for each group and poly (A)+ RNA was isolated from total RNA using the poly $(\mathrm{A}+$ ) Tract mRNA isolation systems (Promega, Madison, WI). In this way we tried to reduce the variation due to the individual mice by averaging over 10 individuals. Poly(A)+ RNA was labeled with Cy5 and Cy3 fluorescent dyes for microarray hybridization as described [9]. Experiments were performed in duplicate using technical replication: the same RNAs were labeled, divided into two different pools and hybridized onto two different GEMs 2.03 microarrays containing 10176 spots of which 192 controls (Incyte Genomics, Palo Alto, CA). cDNA arrays were scanned for both fluorescent signals (Cy5, Cy3) and the data were analyzed using the GEMTools software version 2.5.1 (Incyte Genomics, Palo Alto, CA). For normalization, GEMTools uses a signal correction algorithm to correct for different rates of incorporation of the $\mathrm{Cy} 3$ and $\mathrm{Cy} 5$ dyes [9]. In an optimal hybridization both dyes are incorporated at similar rates. In this case, a scatterplot of the $\log \mathrm{Cy} 3$ signal versus the $\log \mathrm{Cy} 5$ signal should show a signal distribution along a line with a slope of 1 . The signal correction algorithm tests whether the slope of the regression line for the $\log \mathrm{Cy} 3$ signal versus the $\log \mathrm{Cy} 5$ signal is 1. If not, GEMTools applies a regression model to rotate the regression line to a slope of 1 . To determine if the signal was sufficiently high above background and was not the result of non-uniform noise on spotted DNA sites, a spot was included in the analysis if it showed a signal to background ratio of minimal 2.5 , a signal intensity above 250 arbitrary units for one or both dyes, and a spot size of at least $40 \%$ of the spotted area.

\subsection{Statistical analysis}

Experiments were performed in duplicate and gene expression profiles (log ratios) were measured for each experiment (array). To determine significant differential gene expression the $z$-test was used on the natural log transformed expression ratios of these duplicate arrays, using all valid measurements according to the above criteria. The $z$-test is a statistical test similar to the $t$-test. In contrast with the $t$ test, for the $z$-test it is possible to achieve a sufficient sensitivity with only two replicates using a more accurate error estimation (fitted S.D.) by calculating the error from all the genes on the array. In this manner, the variance is based on a large number of observations in an experiment, instead of only two. The observed expression S.D.s based on the replicate signals are plotted against the average log signal intensities per gene. On the observed S.D.s a line is fitted to calculate a gliding mean over the errors according to the signal intensities (fitted S.D.s), because error can be large relative to low signal intensities [10,11]. A $z$-statistic with the fitted S.D. is used instead of the t-statistic using the observed S.D.(s) based on only two replicates. Based on the $z$-test, the overall minimal significant difference in expression $\left(p<1 \times 10^{-3}\right)$ was determined at fold change $(\mathrm{FC})=1.4$. Significant differentially expressed genes were filtered using Spotfire ${ }^{\circledR}$ DecisionSite ${ }^{\mathrm{TM}}$ (Spotfire Inc., Massachusetts, USA) [12].

\subsection{Functional classification of genes present on the cDNA array}

Functional gene information from the Gene Ontology database (GO: http://www.geneontology.org/) (March 2003) [5] was obtained using GeneHopper [13]. To gain information on metabolic pathways, LocusLink IDs were run through the Kyoto Encyclopedia of Genes and Genomes (KEGG: www.genome.ad.jp/kegg/) (March 2003) [6]. To determine which functional classes are particularly affected, the chi-square test was performed, where the expected number of differentially expressed genes was calculated as $E=C / T \times D$, where $E$, expected number of genes; $C$, total number of genes per category on chip; $T$, total number of genes on chip and $D$, total number of differentially expressed genes.

\subsection{Confirmation of differences in expression levels}

Primers for genes (Sigma/Genosis) corresponding to Incyte clones were designed according to the manufacturer's protocol using Primer Express ${ }^{\circledR}$ software (Applied Biosystems). One microgram of total RNA was converted to first strand cDNA using random hexamer primers and SuperScript Reverse Transcriptase II (Revert Aid First Strand cDNA Synthesis Kit MBI/Fermentes). cDNA was diluted ( $2 \mathrm{ng} / \mu \mathrm{l})$ and was used for the real time (RT) quantitative PCR reactions using an ABI PRISM ${ }^{\circledR} 7700$ (Applied Biosystems). For a reaction, $5 \mu \mathrm{l}$ cDNA $(2 \mathrm{ng} / \mathrm{ml}), 12.5 \mu 12 X$ PCR MasterMix, $0.5 \mu l$ forward primer, $0.5 \mu l$ reverse primer, $0.75 \mu \mathrm{l} \mathrm{SYBR}$ green and $5.75 \mu \mathrm{l}$ milliQ was used (Eurogentec). PCR conditions were: $2 \mathrm{~min}$ at $50^{\circ} \mathrm{C}, 10 \mathrm{~min}$ at $95^{\circ} \mathrm{C}, 40$ cycles for $15 \mathrm{~s}$ at $95^{\circ} \mathrm{C}, 1 \mathrm{~min}$ at $60^{\circ} \mathrm{C}$, and $15 \mathrm{~s}$ at $95^{\circ} \mathrm{C}, 1 \mathrm{~min}$ at $60^{\circ} \mathrm{C}$, ramp to $95^{\circ} \mathrm{C}(20 \mathrm{~min})$, followed by $15 \mathrm{~s}$ at $95^{\circ} \mathrm{C}$. Data were analyzed using Sequence Detection Software version 1.7 (Applied Biosystems). 
Table 1

Lipid parameters of B6, E3L and E-/- mice on standard diet and different HFC diets

\begin{tabular}{|c|c|c|c|c|c|c|c|c|c|}
\hline \multirow[t]{2}{*}{ Strain } & \multicolumn{3}{|l|}{ Chow diet } & \multicolumn{3}{|l|}{$\mathrm{N}$ diet } & \multicolumn{3}{|l|}{ W diet } \\
\hline & $\mathrm{TC}(\mathrm{mmol} / \mathrm{l})$ & TTG (mmol/l) & Weights (g) & $\mathrm{TC}(\mathrm{mmol} / \mathrm{l})$ & TTG (mmol/l) & Weights (g) & $\mathrm{TC}(\mathrm{mmol} / \mathrm{l})$ & TTG (mmol/l) & Weights $(\mathrm{g})$ \\
\hline B6 & $1.3 \pm 0.3$ & $0.3 \pm 0.1$ & $18.0 \pm 1.1$ & $4.9 \pm 0.5^{*}$ & $0.09 \pm 0.02^{*}$ & $19.2 \pm 1.0$ & NA & NA & NA \\
\hline E3L & $2.4 \pm 0.5^{*}$ & $1.3 \pm 0.6^{*}$ & $19.2 \pm 1.4$ & $54.3 \pm 9.5^{*}$ & $1.3 \pm 0.5$ & $21.1 \pm 1.4$ & $14.8 \pm 3.1^{*}$ & $1.0 \pm 0.5$ & $19.6 \pm 1.0$ \\
\hline E-I- & $10.1 \pm 1.8^{*}$ & $0.5 \pm 0.2$ & $19.9 \pm 1.5$ & NA & NA & NA & NA & NA & NA \\
\hline
\end{tabular}

Lipid parameters of B6, E3L and E-/- mice on different diets. TC, total cholesterol; TTG, total triglyceride. Chow, standard diet; W, moderate HFC diet; N, HFC diet. Total cholesterol and triglyceride values are the mean serum levels \pm S.D. of 7-22 mice per group. Statistical analysis using the nonparametric Mann-Whitney test revealed a significant difference $\left({ }^{*} p<0.0001\right)$ in TC and TTG between B6 and E3L mice on chow, and in TC between B6 and E- $/-$ mice on chow. Furthermore, a significant difference was detected $\left({ }^{*} p<0.0001\right)$ in TC between E3L chow and E3L W, N and in TC and TTG between B6 chow and B6 N. NA, not applicable.

\section{Results}

\subsection{Lipid parameters and histology of the liver}

E-I- mice were maintained on a standard (chow) diet and showed a significant increase in total serum cholesterol (TC) when compared with B6 (Table 1), which is in line with previous data 1. E3L mice were also maintained on a chow diet and showed significant increases in both TC and total triglyceride levels (TTG) when compared with B6 mice (Table 1). In addition, E3L mice were fed a moderate high-fat $\operatorname{diet}(\mathrm{W})$ and the severe high-fat diet $(\mathrm{N})$, which resulted in a pronounced increase in TC (Table 1) when compared with E3L mice on chow, as expected from previous data [2]. In parallel, B6 mice were fed the diet $\mathrm{N}$ showing a significant difference in TC and TTG when compared with B6 mice on chow. Histological examination of the livers revealed fat accumulation in the livers of transgenic mice, as reported earlier, but other pathology was absent [14].

\subsection{Gene expression profiles of the liver}

RNA was isolated from all mice of each experimental condition and pooled to minimize the biological variation between the individual mice. For microarray experiments, Incyte cDNA arrays (GEM2.03) were hybridized simultaneously with a Cy5 labeled cDNA sample from the experimental group, and a Cy3 labeled cDNA control sample (Table 2). The use of cDNA-based arrays implied an experimental design in the form of pair-wise comparisons. Experiments were performed in duplicate, and gene expression profiles (log ra- tios) from duplicate experiments showed a high correlation (Pearson correlation, $r=0.97-0.98)$. To have a better understanding of the mechanisms related to hyperlipidemia and atherosclerosis, the effect of the transgenic alteration on gene expression was examined in chow fed mice. At a cutoff level of 1.4-fold expression ( $p$-value $<1 \times 10^{-3}$, see Section 2 ), 150 and 187 genes were found to be regulated in E3L or E-/mice, respectively, when compared with non-transgenic B6 mice. Upon increasing the dietary fat load using diet N 360 genes showed different expression levels in the comparison between B6 and E3L mice. To study the dietary response, E3L mice were fed diet $\mathrm{W}$ and compared with chow fed E3L mice. We found 200 genes to be affected by diet W. A more pronounced effect, however, was found using diet N. Some 788 genes in B6 mice and 1010 genes in E3L mice were differentially regulated. The complete dataset can be found in the supplementary materials (Table I, on the web). The majority of the genes showed a fold change of 1.4-2.0, while 184 genes displayed differences between 2- and 20-fold change.

\subsection{Specific pathways involved in the dietary response}

All genes on the chip were classified using the GO database, which is a hierarchical database that classifies all genes regarding their biological process, molecular function and cellular compartment. Based on GO, all 9552 genes present on the chip were categorized into 39 functional classes. Sixty percent of the genes could be categorized into these functional classes. However, the biological role of $40 \%$ of these genes remained unknown. Genes that were involved in more than one biological process were catego-

Table 2

Outline of the microarray experiments

\begin{tabular}{|c|c|c|c|c|c|}
\hline \multicolumn{2}{|c|}{ Experimental group } & \multicolumn{2}{|c|}{ Control group } & \multirow[t]{2}{*}{ Variable } & \multirow[t]{2}{*}{ Number of genes } \\
\hline Strain & Diet & Strain & Diet & & \\
\hline E3L & Chow & B6 & Chow & APOE3Leiden transgene & 150 \\
\hline E-I- & Chow & B6 & Chow & ApoE knockout & 187 \\
\hline E3L & $\mathrm{N}$ & B6 & $\mathrm{N}$ & APOE3Leiden transgene & 360 \\
\hline E3L & $\mathrm{W}$ & E3L & Chow & Diet & 200 \\
\hline B6 & $\mathrm{N}$ & B6 & Chow & Diet & 788 \\
\hline E3L & $\mathrm{N}$ & E3L & Chow & Diet & 1010 \\
\hline
\end{tabular}

Experimental conditions used for microarray experiments to study the effect of the APOE3Leiden transgene, ApoE deficiency and dietary gene regulation. The number of differentially regulated genes per condition are shown. Experimental group: Cy5, control group: Cy3. 

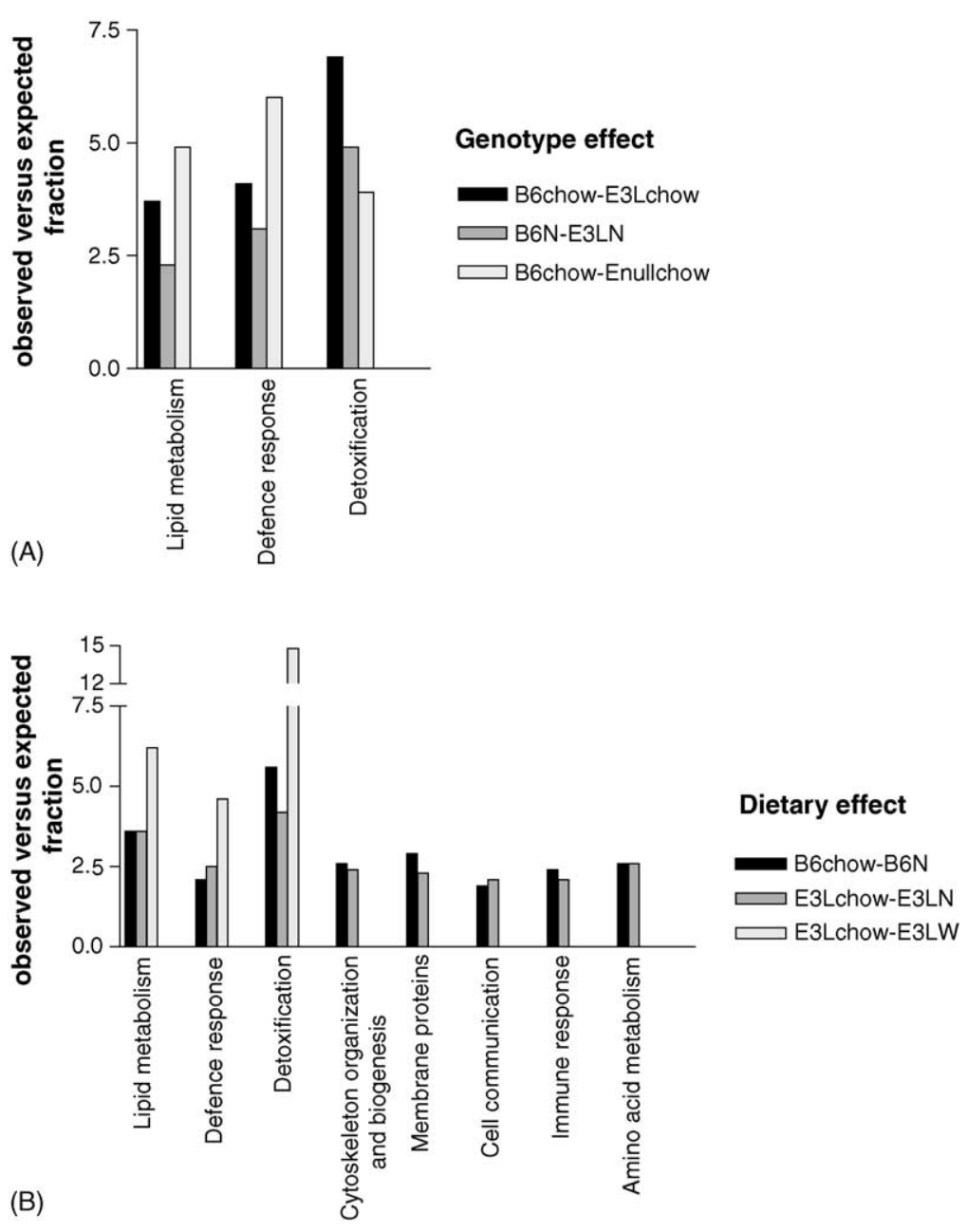

Fig. 1. Functional classes with a significantly increased number of differentially expressed genes ( $p<0.01$, chi-square test): (A) affected by genotype and (B) affected by diet.

rized in the most relevant category for our study. Notably, glutathione $S$-transferases and monooxygenases were categorized as detoxification genes, membrane proteins were categorized on the basis of the cellular compartment. Subsequently, differentially expressed genes categorized according to these 39 functional classes were identified (Table I, on the web). This allowed comparison of the functional classes over the different conditions. The major classes that were regulated over all the different conditions included lipid metabolism, transport, enzymes and inflammation, the latter represented by the immune/defense response, and detoxification. Lipid metabolism and enzymes were highly represented in the conditions studying the genotype. Strikingly, the expression profile of the response of $\mathrm{B} 6$ and E3L mice to diet $\mathrm{N}$ was highly similar. The effect of diet $\mathrm{W}$ in the E3L mice was less pronounced, but showed several similar functional classes as regulated by diet $\mathrm{N}$, such as lipid metabolism, enzymes and detoxification processes.

To determine which processes were particularly affected upon perturbation of the lipid metabolism by genetic alterations or diet, the number of genes present on the chip that belong to a particular category was determined using the categories of the GO database (Table I, on the web). All classes with a significant increased number of differentially expressed genes are shown (Fig. 1). Lipid metabolism, the defense response and detoxification pathways were significantly affected by expression of APOE3Leiden and by ApoE deficiency. These pathways were also strongly regulated by diet $\mathrm{W}$ and $\mathrm{N}$. Moreover, in view of the large number of genes regulated by diet $\mathrm{N}$ several other functional classes were identified in the experiment comparing the $\mathrm{B} 6$ and $\mathrm{E} 3 \mathrm{~L}$ mice. These classes were the immune response, cytoskeleton organization and biogenesis, membrane proteins, cell communication and amino acid metabolism.

\subsection{Sub-classification of genes involved in lipid and detoxification metabolism revealed many nuclear receptor target genes}

The two most relevant categories as indicated above, i.e. lipid and detoxification metabolism, have been further explored using the KEGG database by categorizing the genes 
Table 3

Metabolic pathways involved in lipid and detoxification processes based on the KEGG database

\begin{tabular}{|c|c|c|c|c|c|c|c|}
\hline \multicolumn{8}{|l|}{ Lipid metabolism } \\
\hline Pathways & Gene & \multirow[b]{2}{*}{ 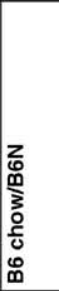 } & \multirow[b]{2}{*}{ 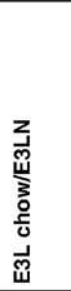 } & \multirow[b]{2}{*}{ 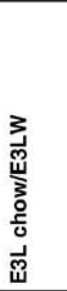 } & \multirow[b]{2}{*}{ 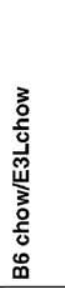 } & \multirow[b]{2}{*}{ 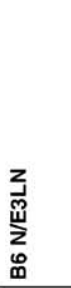 } & \multirow[b]{2}{*}{ 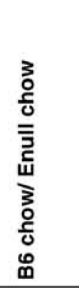 } \\
\hline & & & & & & & \\
\hline \multirow[t]{5}{*}{ Fatty acid metabolism } & cytochrome P450, 1a2, aromatic compound inducible & -2.15 & -4.10 & -1.70 & 1.15 & -1.65 & -1.60 \\
\hline & cytochrome P450, 2a4 & -1.65 & -4.25 & -1.65 & 1.35 & -2.00 & -1.10 \\
\hline & cytochrome $\mathrm{P} 450,2 \mathrm{~b} 10$, phenobarbitol inducible, type b & -3.60 & -3.60 & -1.40 & -1.35 & -1.20 & -5.90 \\
\hline & cytochrome P450, steroid inducible 3a11 & -2.60 & -1.95 & -2.30 & -1.45 & -1.20 & -1.45 \\
\hline & fatty acid binding protein 1 , liver & -2.20 & -3.50 & -1.55 & -1.05 & -1.60 & -1.10 \\
\hline Fatty acid biosynthesis & stearoyl-Coenzyme A desaturase 1 & 3.15 & 2.65 & 1.55 & -1.15 & -1.10 & -1.50 \\
\hline \multirow[t]{2}{*}{ Bile acid biosynthesis } & cytochrome P450, 7a1 (cholesterol 7alpha-hydroxylase) & -2.40 & -2.00 & 2.40 & -1.45 & 1.05 & 1.00 \\
\hline & cytochrome P450, 7b1 & 1.15 & 1.50 & 1.65 & 1.15 & 1.45 & 1.40 \\
\hline \multirow[t]{2}{*}{ C21-Steroid hormone metabolism } & cytochrome P450, 17 & -3.45 & -2.05 & 1.05 & -2.00 & -1.10 & -1.80 \\
\hline & hydroxysteroid 11-beta dehydrogenase 1 & -2.05 & -2.10 & -1.55 & -1.50 & -1.30 & -1.25 \\
\hline \multirow[t]{2}{*}{ Androgen and estrogen metabolism } & cytochrome P450, 7b1 & 1.15 & 1.50 & 1.65 & 1.15 & 1.45 & 1.40 \\
\hline & hydroxysteroid 11-beta dehydrogenase 1 & -2.05 & -2.10 & -1.55 & -1.50 & -1.30 & -1.25 \\
\hline \multirow[t]{2}{*}{ Apolipoproteins } & apolipoprotein All & -1.85 & -2.65 & -1.40 & -1.15 & -1.65 & -1.40 \\
\hline & apolipoprotein E & 1.85 & 1.40 & 1.25 & 1.40 & -1.00 & -20.85 \\
\hline Lipid transporters & solute carrier family 27 (fatty acid transporter), member 5 & -2.20 & -2.65 & -1.10 & -1.35 & -1.55 & -1.55 \\
\hline \multirow[t]{2}{*}{ ABC transporters } & ATP-binding cassette, sub-family D (ALD), member 3 & -2.10 & -2.15 & -1.40 & -1.50 & -1.55 & -1.55 \\
\hline & ATP-binding cassette, sub-family G (WHITE), member 5 & 1.75 & 1.60 & 1.55 & -1.20 & -1.50 & -1.55 \\
\hline \multicolumn{8}{|l|}{ Detoxification processes } \\
\hline Styrene degradation & cytochrome P450, 7b1 & 1.15 & 1.50 & 1.65 & 1.15 & 1.45 & 1.40 \\
\hline 1,4-Dichlorobenzene degradation & cytochrome P450, 7b1 & 1.15 & 1.50 & 1.65 & 1.15 & 1.45 & 1.40 \\
\hline \multirow{7}{*}{$\begin{array}{l}\text { gamma-Hexachlorocyclohexane } \\
\text { degradation }\end{array}$} & cytochrome P450, 1a2, aromatic compound inducible & -2.15 & -4.10 & -1.70 & 1.15 & -1.65 & -1.60 \\
\hline & cytochrome P450, 2a4 & -1.65 & -4.25 & -1.65 & 1.35 & -2.00 & -1.10 \\
\hline & cytochrome $\mathrm{P} 450,2 \mathrm{~b} 10$, phenobarbitol inducible, type $\mathrm{b}$ & -3.60 & -3.60 & -1.40 & -1.35 & -1.20 & -5.90 \\
\hline & cytochrome P450, steroid inducible 3a11 & -2.60 & -1.95 & -2.30 & -1.45 & -1.20 & -1.45 \\
\hline & cytochrome P450, 4a10 & -3.90 & -4.85 & -1.75 & -1.20 & -1.45 & 1.05 \\
\hline & cytochrome P450, 4a14 & -5.20 & -6.15 & -2.35 & -1.20 & -1.50 & 1.10 \\
\hline & cytochrome P450, 7b1 & 1.15 & 1.50 & 1.65 & 1.15 & 1.45 & 1.40 \\
\hline \multirow[t]{2}{*}{ Glutathione metabolism } & glutathione S-transferase, alpha 3 & -2.00 & -3.00 & -1.60 & 1.05 & -1.60 & -1.10 \\
\hline & glutathione S-transferase, pi 2 & 2.35 & -1.20 & -2.50 & 2.15 & -1.30 & 1.50 \\
\hline
\end{tabular}

Differentially expressed genes involved in lipid metabolism and detoxification pathways are indicated. Nuclear receptor target genes are indicated in bold. The average fold changes from the duplicate experiments are indicated. Upregulated genes are indicated in dark gray, downregulated genes are indicated in light gray.

into the following metabolic processes; (1) bile acid, (2) fatty acid, (3) sterol biosynthesis, (4) steroid metabolism and (5) detoxification pathways. Table II (on the web) shows 94 genes falling into 17 different functional classes. The greatest effects on gene expression were modulated by diet $\mathrm{N}$, leading to the suppression of $70 \%$ of the genes. Twenty genes were found that were regulated in at least four conditions (Table 3). These genes included key enzymes of the bile acid biosynthesis and steroid pathway respectively; cholesterol 7- $\alpha$ hydroxylase (Cyp7a1), oxysterol 7- $\alpha$ hydroxylases (Cyp7b1), cytochrome p450 (Cyp)17 and hydroxysteroid (11-beta) dehydrogenase $1(H s d l 1 b)$. Also several genes involved in fatty acid metabolism were regulated such as Cypla2, Cyp2a4, Cyp2b10, Cyp3a11, fatty acid binding protein 1 (Fabp-1), solute carrier family 27 gene (Slc27) and stearoyl-Coenzyme A desaturase 1 ( $S c d l)$. Two lipid transporters the ATP-binding cassette, subfamily D 3 ( $A b c d 3$ ) and $A b c g 5$ were also strongly regulated. Cyp1a2, Cyp2a4, Cyp2b10 and Cyp3a11 also play major roles in detoxification processes. Other detoxification genes that were regulated were Cyp4a10, Cyp4a14 and several glutathione $S$-transferases (GSTs) namely Gsta3 and Gstp2. Many of these genes are known to play an instrumental role during lipid metabolism, although for several genes this role remains less clear. To obtain detailed indications of the molecular mechanism underlying this gene regulation, genes have been indicated (based on literature data) that are under the regulation of the nuclear receptors FXR, PXR, CAR, LXR, hepatocyte nuclear factor $4 \alpha$ (HNF- $4 \alpha$ ), PPARs and SREBPs. Thirty-nine nuclear receptor target genes were identified involved in the different metabolic pathways associated with lipid metabolism and detoxification processes (Table II). An overview of these genes and the way they are regulated in this study and other studies is provided in Table 4. Intriguingly, 15 of these genes are part of the total group of 
Table 4

Nuclear receptor target genes

\begin{tabular}{|c|c|c|c|c|c|c|c|c|c|c|c|}
\hline Gene & $\mathrm{W}$ & $\mathrm{N}$ & FXR & PXR/CAR & LXR & $\operatorname{PPAR} \alpha$ & PPAR $\delta$ & HNF- $4 \alpha$ & $\begin{array}{l}\text { SREBP } \\
1 \mathrm{a}, 1 \mathrm{c}, 2\end{array}$ & Ref. & Tissue \\
\hline Abca1 & - & $\uparrow$ & & & $\uparrow$ & & & & & {$[25] *$} & $\mathrm{~m} \Phi$, Intestine \\
\hline Abcb1 (Mdr1) & $\downarrow$ & $\uparrow$ & & $\uparrow$ & & & & & & {$[26] \ddagger$} & Liver \\
\hline Abcb4 (Mdr2) & $\downarrow$ & - & & & & $\uparrow$ & & & & {$[7] *$} & Liver \\
\hline Abcc2 (Mrp2) & - & $\downarrow$ & $\uparrow$ & $\uparrow$ & & & & $\uparrow$ & & {$[27] *,[28] \ddagger$} & Liver \\
\hline Abcd 3 & $\downarrow$ & $\downarrow$ & & & & $\uparrow$ & & & & {$[7] \ddagger$} & Liver \\
\hline Abcg1 & nd & $\uparrow$ & & & $\uparrow$ & & & & & {$[25] \ddagger$} & $\mathrm{m} \Phi$ \\
\hline Abcg5 & $\uparrow$ & $\uparrow$ & & & $\uparrow$ & & & & & {$[25]^{*}$} & Liver, intestine \\
\hline Acox1 & - & $\downarrow$ & & & & $\uparrow$ & $\uparrow$ & & & {$[7] *,[29] \ddagger$} & Liver adipose tissue \\
\hline Aldh $3 \mathrm{a} 2$ & - & $\downarrow$ & & $\uparrow$ & & & & & & {$[30] \ddagger$} & Liver \\
\hline ApoA-I & - & $\uparrow$ & $\downarrow$ & & & $\uparrow$ & & $\uparrow$ & & {$[21] *,[7] *,[28] *$} & Liver \\
\hline ApoA-II & $\downarrow$ & $\downarrow$ & & & & $\uparrow$ & & $\uparrow$ & & {$[7] *,[28] *$} & Liver \\
\hline ApoA-V & - & $\downarrow$ & & & & $\uparrow$ & & & & {$[31] *$} & Liver \\
\hline ApoC-II & - & $\uparrow$ & $\uparrow$ & & $\uparrow$ & & & $\uparrow$ & & {$[20] *,[28] *$} & Liver \\
\hline ApoC-IV & - & $\downarrow$ & & & $\uparrow$ & & & & & {$[25]^{*}$} & Liver, $\mathrm{m} \Phi$ \\
\hline ApoE & - & $\uparrow$ & $\uparrow$ & & $\uparrow$ & & & $\uparrow$ & & {$[20] *,[25] *,[28] *$} & Liver, $m \Phi$, adipocytes \\
\hline Cyp1a2 & $\downarrow$ & $\downarrow$ & & $\uparrow$ & & & & & & {$[32] \ddagger$} & Liver \\
\hline Сур2b9/10 & $\downarrow$ & $\downarrow$ & & $\uparrow$ & & & & & & {$[30] *$} & Liver \\
\hline Cyp2a4/2a5 & $\downarrow$ & $\downarrow$ & & $\uparrow$ & & & & & & {$[30] \ddagger$} & Liver \\
\hline Сур3a11 & $\downarrow$ & $\downarrow$ & $\downarrow$ & $\uparrow$ & & & & & & {$[30] *,[33] \dagger$} & Liver \\
\hline Cyp4a10 & $\downarrow$ & $\downarrow$ & & $\downarrow$ & & & & & & {$[30] \ddagger$} & Liver \\
\hline Cyp4a14 & $\downarrow$ & $\downarrow \downarrow$ & & $\downarrow$ & $\uparrow$ & & & & & {$[30] \ddagger,[25] \ddagger$} & Liver \\
\hline Cyp7a1 & $\uparrow$ & $\downarrow$ & $\downarrow$ & $\downarrow$ & $\uparrow$ & & & $\uparrow$ & & {$[34] *[19] *,[25] *[28] *$} & Liver \\
\hline Fas & - & $\downarrow$ & & & $\uparrow$ & & & & $\downarrow$ & {$[25] *,[35] *$} & Liver \\
\hline Ftdf1 & $\downarrow$ & $\downarrow$ & & & & & & & $\uparrow$ & {$[36] \ddagger$} & Liver \\
\hline Gst- $\alpha 3$ & $\downarrow$ & $\downarrow$ & & $\uparrow$ & & & & & & {$[30] \ddagger$} & Liver \\
\hline Gst- $\alpha 4$ & $\downarrow$ & - & & $\uparrow$ & & & & & & {$[30] \ddagger$} & Liver \\
\hline Gst mu1 & $\downarrow$ & $\uparrow$ & & $\uparrow$ & & & & & & {$[30] \ddagger$} & Liver \\
\hline Gst mu2 & $\downarrow$ & $\uparrow$ & & $\uparrow$ & & & & & & {$[30] \ddagger$} & Liver \\
\hline Gst pi2 & $\downarrow$ & $\uparrow$ & & $\downarrow$ & & & & & & {$[30] \ddagger$} & Liver \\
\hline Hmgcr & - & $\downarrow$ & & & & & & $\uparrow$ & $\uparrow$ & {$[36] *,[28] \ddagger$} & Liver \\
\hline L-fabp & $\downarrow$ & $\downarrow$ & & & & $\uparrow$ & & $\uparrow$ & & {$[7] *,[28] \ddagger$} & Liver \\
\hline Lpl & - & $\uparrow$ & & & $\uparrow$ & $\uparrow$ & & & & {$[25] \ddagger,[7] *$} & Periphery \\
\hline Mup2 & - & $\downarrow \downarrow$ & & $\downarrow$ & & & & & & {$[30] \ddagger$} & Liver \\
\hline Pltp & - & $\uparrow$ & $\uparrow$ & & $\uparrow$ & & & & & {$[37] *,[20] *$} & Liver \\
\hline Scd-1 & $\uparrow$ & $\uparrow$ & & & $\uparrow$ & & & & & {$[25] *$} & Liver \\
\hline Squalene epoxidase & $\downarrow$ & - & & & & & & & $\uparrow$ & {$[38] *$} & Liver \\
\hline Vlcad & - & $\downarrow$ & & & & $\uparrow$ & $\uparrow$ & & & {$[39] *,[29] \ddagger$} & Liver \\
\hline
\end{tabular}

Dietary regulation $(\mathrm{W}, \mathrm{N})$ of nuclear receptor target genes is indicated and the manner of regulation found in this study and as previously reported for the several nuclear receptors. $(*)$ Indicates a direct nuclear receptor target gene based on promoter studies, $(\dagger)$ nuclear receptor gene regulation based on dietary studies in mice, $\ddagger$ nuclear receptor gene regulation based on expression profiling studies in vitro and in vivo. (-) No change, ( $\uparrow)$ upregulated, ( $\downarrow)$ downregulated, ( $\uparrow \uparrow)$ or $(\downarrow \downarrow)$ greater than five times FC. Genes confirmed by quantitative RT-PCR are in bold.

20 genes (i.e. 75\%) that were expressed in at least four conditions (Table 3).

\subsection{Confirmation of differentially expressed genes by real time quantitative $P C R$}

Representative genes for the different lipid pathways and detoxification processes as well as some other genes were selected for validation using real time (RT) quantitative PCR. Differential expression of Cyp7a1, Slc27, Scd1, Cyp2a4, farnesyl diphosphate farnesyl transferase 1 (Ftdf), Cyp39al, Cyp17, Hsd11b1, Abcal, the apolipoprotein ApoH and insulin growth factor binding protein 1 (Igfbpl) could be confirmed for all conditions by RT quantitative PCR using cyclophilin as reference (Table 4, Fig. I, on the web). Fold changes even as low as 1.2, could be confirmed using RTPCR (Fig. I, on the web). Expression of the inflammatory gene, tumor necrosis factor alpha $(T N F \alpha)$, was also determined by RT-PCR and showed a strong induction ( $\sim 15$-fold) by diet $\mathrm{N}$ in $\mathrm{B} 6$ and $\mathrm{E} 3 \mathrm{~L}$ mice but not in the other conditions (Fig. I, on the web).

\section{Discussion}

This study was aimed at delineating the events related to hyperlipidemia and atherosclerosis at the level of gene expression using microarray analysis. Therefore, two related approaches were used; the effect of genotype and environment (diet) on the gene expression profile in the mouse liver was studied using E-/- and E3L mice. The different modi- 
fications of APOE in both the E3L and E-/- mice resulted in similar pathways that were affected. Interestingly, the related pathways detected in these comparisons indicated a similar compensatory mechanism responding to the changes in lipoprotein metabolism in both these genetically altered mice. In line with this similar overall response, several cholesterol responsive genes were regulated in both models. Possibly, these genes may represent the convergences in the pathways affected in the two mouse models. This study showed that the genomic analysis of transgenic and knockout models was an excellent approach to define the molecular pathways related to hyperlipidemia.

Similar to that observed in the experiments addressing the genotype effects, the lipid metabolism, detoxification and defense response genes were significantly over represented among the regulated genes when using the mild high fat diet $\mathrm{W}$, which lacks cholate. A more pronounced response was observed in case the 'atherogenic' diet N, containing $0.5 \%$ cholate, had been used. The E3L and the B6 mice showed a highly similar response resulting in the differential expression of 800-1000 genes. Remarkably, although the E3L mice on diet $\mathrm{N}$ have a $\sim 9$-fold higher plasma cholesterol level than the $\mathrm{B} 6$ mice on diet $\mathrm{N}$, this much greater susceptibility to diet induced hyperlipidemia did not lead to the detection of a much higher number of response genes. Therefore, it is likely that the same pathways are activating in the same models. It is of interest to know whether this finding holds true for other models as well. The expression profiles were characterized by the over representation of the former three classes and the immune response, cytoskeleton organization and biogenesis, membrane proteins, cell communication and amino acid metabolism. These results showed that high-fat feeding had a much stronger effect than the effects observed in the previous experiments examining the effect of the genetic modifications of APOE. Moreover, a recent study using microarrays to examine the effects of a cholesterol $(1.25 \%)$ and cholate $(0.5 \%)$ containing diet in livers of B6 mice already indicated widespread changes in hepatic gene expression, affecting the expression of over 1200 genes. Many genes were associated with inflammatory-related processes such as immune/defense response genes and extracellular matrix proteins. Furthermore, when studying diets with only cholesterol or cholate, it was found that inflammatory gene activation was dependent on the presence of cholesterol in the diet, whereas the extracellular matrix proteins were specifically induced by cholate [16]. These results corresponded with our results; diet $\mathrm{N}$ had a significant effect on the cytoskeleton organization and biogenesis pathway that consisted of many extracellular matrix proteins.

Several genes were not only regulated during the dietary challenges but also during the other conditions examining the effect of the genetic modifications of APOE. These genes may be particularly of interest for further study, because they may play instrumental roles under hyperlipidemic conditions. Several of these genes were already shown to be the cause of lipid disorders. For instance, mutations in $C y p 7 b 1$ and $A b c g 5$ resulted in, respectively, neonatal cholestasis [17] and sitosterolemia [18]. Intriguingly, more strongly regulated genes such as Cyp4a10 and Cyp4a14 were found that are not previously associated with lipid disorders.

To identify common regulatory pathways related to lipid and detoxification pathways, data regarding these pathways were integrated with published data concerning gene regulation through nuclear receptors. Nuclear receptors become activated to drive gene expression upon binding to (metabolites of) bile acids, fatty acids and cholesterol. We found many nuclear receptor target genes of which several were commonly regulated during the different conditions. HFC diets affected all nuclear receptors: FXR, PXR, CAR, LXR, PPAR$\alpha / \delta, \mathrm{HNF}-4 \alpha$ and SREBPs. Except for ApoA-I and $A b c c 2$, all FXR responsive genes were regulated by $\operatorname{diet} \mathrm{N}$ in a similar manner of up/down regulation as was previously described [19-21]. Intriguingly, the regulation of ApoA-I by fatty acids through PPAR $\alpha$ was dominant over the regulation by cholate through FXR. For several genes a different regulatory mechanism was seen as was described in literature. This may be due to differences in dietary composition between experiments. Moreover, the complex regulation in which lipids may not just affect one receptor may result in different effects on gene expression [7]. It is likely that the observed effects on gene regulation are partly due to the cholate present in diet N. Except for the direct regulation by bile acids of the FXR [19] and the detoxification receptors PXR/CAR [22], no other nuclear receptors are known to be directly regulated by bile acids in liver. Additionally, previous studies already indicated the effects of lipids on immune and inflammatory responses involving nuclear receptors such as the PPARs and the LXRs $[23,24]$. However, findings described in this study also implicated roles for other nuclear receptors in this process.

In conclusion, the common regulation of many nuclear receptor target genes underlying lipid and detoxification processes as found in this study, suggest a defense mechanism involving many nuclear receptors to protect against the accumulation of toxic endogenous lipids and bile acids. Intriguingly, most of the strongest regulated genes were also nuclear receptor target genes, which may implicate that they are key genes in regulatory pathways related to lipid metabolism. This makes these genes very good candidates for further studies. These observations further strengthen the close link between lipid metabolism and inflammatory-related processes.

\section{Acknowledgments}

This project was supported by a grant from the Dutch Organization for Scientific Research (project NWO 98010001). M.H. Hofker is Established Investigator of the Dutch Heart Association (project NHS D95022). C.J.A. Moen is research fellow of the Dutch Organization for Scientific Research (project NWO 903-39-174). We would like to thank Chris Evelo and Payman Hanifi Moghaddam for helping with data analysis. 


\section{Appendix A. Supplementary data}

Supplementary data associated with this article can be found, in the online version, at doi:10.1016/j.atherosclerosis. 2005.01.049.

\section{References}

[1] Zhang SH, Reddick RL, Piedrahita JA, Maeda N. Spontaneous hypercholesterolemia and arterial lesions in mice lacking apolipoprotein E. Science 1992;258:468-71.

[2] van Vlijmen BJ, van den Maagdenberg AM, Gijbels MJ, et al. Dietinduced hyperlipoproteinemia and atherosclerosis in apolipoprotein E3-Leiden transgenic mice. J Clin Invest 1994;93:1403-10.

[3] Nishina PM, Verstuyft J, Paigen B. Synthetic low and high fat diets for the study of atherosclerosis in the mouse. J Lipid Res 1990;3:859-69.

[4] Nishina PM, Wang J, Toyofuku W, Kuypers FA, Ishida BY, Paigen B. Atherosclerosis and plasma and liver lipids in nine inbred strains of mice. Lipids 1993;28:599-605.

[5] Ashburner M, Ball CA, Blake JA, et al. Gene ontology: tool for the unification of biology. The Gene Ontology Consortium. Nat Genet 2000;25:25-9.

[6] Goto S, Bono H, Ogata H, et al. Organizing and computing metabolic pathway data in terms of binary relations. Pac Symp Biocomput 1997:175-86.

[7] Chawla A, Repa JJ, Evans RM, Mangelsdorf DJ. Nuclear receptors and lipid physiology: opening the X-files. Science 2001;294:1866-70.

[8] van den Maagdenberg AM, Hofker MH, Krimpenfort PJ, et al. Transgenic mice carrying the apolipoprotein E3-Leiden gene exhibit hyperlipoproteinemia. J Biol Chem 1993;268:10540-5.

[9] Yue H, Eastman PS, Wang BB, et al. An evaluation of the performance of cDNA microarrays for detecting changes in global mRNA expression. Nucleic Acids Res 2001;29(8):E41-51.

[10] Nadon R, Shi P, Skandalis A. Statistical inference methods for gene expression arrays. In: Bittner MM, editor. Microarrays: optical technologies and informatics. Proc SPIE 2001;4266:46-55.

[11] Kerr MK, Churchill GA. Statistical design and the analysis of gene expression microarray data. Genet Res 2001;77:123-8.

[12] Ahlberg C. Visual exploration of HTS databases: bridging the gap between chemistry and biology. Drug Discov Today 1999;4:370-6.

[13] Svensson BA, Kreeft AJ, Van Ommen GJ, Den Dunnen JT, Boer JM. GeneHopper: a web-based search engine to link geneexpression platforms through GenBank accession numbers. Genome Biol 2003;4:R35.

[14] Mensenkamp AR, van Luyn MJ, van Goor H, et al. Hepatic lipid accumulation, altered very low density lipoprotein formation and apolipoprotein E deposition in apolipoprotein E3-Leiden transgenic mice. J Hepatol 2000;33:189-98.

[16] Vergnes L, Phan J, Strauss M, Tafuri S, Reue K. Cholesterol and cholate components of an atherogenic diet induce distinct stages of hepatic inflammatory gene expression. J Biol Chem 2003;278:42774-84.

[17] Setchell KD, Schwarz M, O'Connell NC, et al. Identification of a new inborn error in bile acid synthesis: mutation of the oxysterol 7alpha-hydroxylase gene causes severe neonatal liver disease. J Clin Invest 1998;102:1690-703.

[18] Berge KE, Tian H, Graf GA, et al. Accumulation of dietary cholesterol in sitosterolemia caused by mutations in adjacent $\mathrm{ABC}$ transporters. Science 2000;290:1771-5.

[19] Makishima M, Okamoto AY, Repa JJ, et al. Identification of a nuclear receptor for bile acids. Science 1999;284:1362-5.
[20] Mak PA, Kast-Woelbern HR, Anisfeld AM, Edwards PA. Identification of PLTP as an LXR target gene and apoE as an FXR target gene reveals overlapping targets for the two nuclear receptors. J Lipid Res 2002;43:2037-41.

[21] Claudel T, Sturm E, Duez H, et al. Bile acid-activated nuclear receptor FXR suppresses apolipoprotein A-I transcription via a negative FXR response element. J Clin Invest 2002;109:961-71.

[22] Kliewer SA, Willson TM. Regulation of xenobiotic and bile acid metabolism by the nuclear pregnane $\mathrm{X}$ receptor. J Lipid Res 2002;43:359-64.

[23] Bocher V, Chinetti G, Fruchart JC, Staels B. Role of the peroxisome proliferator-activated receptors (PPARS) in the regulation of lipids and inflammation control. J Soc Biol 2002;196:47-52.

[24] Joseph SB, Castrillo A, Laffitte BA, Mangelsdorf DJ, Tontonoz P. Reciprocal regulation of inflammation and lipid metabolism by liver X receptors. Nat Med 2003;9:213-9.

[25] Tontonoz P, Manglesdorf DJ. LXR signaling pathways in cardiovascular disease. Mol Endocrinol 2003;17:985-93.

[26] Synold TW, Dussault I, Forman BM. The orphan nuclear receptor SXR coordinately regulates drug metabolism and efflux. Nat Med 2001;7:584-90.

[27] Kast HR, Goodwin B, Tarr PT, et al. Regulation of multidrug resistance-associated protein $2(\mathrm{ABCC} 2)$ by the nuclear receptors pregnane $\mathrm{X}$ receptor, farnesoid $\mathrm{X}$-activated receptor, and constitutive androstane receptor. J Biol Chem 2002;277:2908-15.

[28] Hayhurst GP, Lee YH, Lambert G, Ward JM, Gonzalez FJ. Hepatocyte nuclear factor 4alpha (nuclear receptor 2A1) is essential for maintenance of hepatic gene expression and lipid homeostasis. Mol Cell Biol 2001;21:1393-403.

[29] Wang YX, Lee CH, Tiep S, et al. Peroxisome-proliferator-activated receptor delta activates fat metabolism to prevent obesity. Cell 2003;113:159-70.

[30] Rosenfeld JM, Vargas RJ, Xie W, Evans RM. Genetic profiling defines the xenobiotic gene network controlled by the nuclear receptor PXR. Mol Endocrinol, in press.

[31] Prieur X, Coste H, Rodriguez JC. The human apolipoprotein AV gene is regulated by peroxisome proliferator-activated receptor-alpha and contains a novel farnesoid $\mathrm{X}$-activated receptor response element. J Biol Chem 2003;278:25468-80.

[32] Maglich JM, Stoltz CM, Goodwin B, Hawkins-Brown D, Moore JT, Kliewer SA. Nuclear pregnane $X$ receptor and constitutive androstane receptor regulate overlapping but distinct sets of genes involved in xenobiotic detoxification. Mol Pharmacol 2002;62:638-46.

[33] Ourlin JC, Lasserre F, Pineau T, et al. The small heterodimer partner interacts with the pregnane $\mathrm{X}$ receptor and represses its transcriptional activity. Mol Endocrinol 2003;17:1693-703.

[34] reviewed in: Goodwin B, Gauthier KC, Umetani M, et al. Identification of bile acid precursors as endogenous ligands for the nuclear xenobiotic pregnane X receptor. Proc Natl Acad Sci USA 2003;100:223-8.

[35] Latasa MJ, Griffin MJ, Moon YS, Kang C, Su lHS. Occupancy and function of the -150 sterol regulatory element and -65 E-box in nutritional regulation of the fatty acid synthase gene in living animals. Mol Cell Biol 2003;23:5896-907.

[36] Sakakura Y, Shimano H, Sone H, et al. Sterol regulatory elementbinding proteins induce an entire pathway of cholesterol synthesis. Biochem Biophys Res Commun 2001;286:176-83.

[37] Urizar NL, Dowhan DH, Moore DD. The farnesoid X-activated receptor mediates bile acid activation of phospholipid transfer protein gene expression. J Biol Chem 2000;275:39313-7.

[38] Nagai M, Sakakibara J, Nakamura Y, Gejyo F, Ono T. SREBP-2 and NF-Y are involved in the transcriptional regulation of squalene epoxidase. Biochem Biophys Res Commun 2002;295:74-80.

[39] Berger J, Moller DE. The mechanisms of action of PPARs. Annu Rev Med 2002;53:409-35. 